\title{
GOSPODARCZE SKUTKI OKUPACJI GALICJI PRZEZ WOJSKO ROSYJSKIE W 1809 ROKU
}

\author{
Michał Baczkowski (D) http://orcid.org/0000-0002-9717-1046 \\ Uniwersytet Jagielloński w Krakowie
}

\begin{abstract}
ECONOMIC CONSEQUENCES OF THE OCCUPATION OF GALICIA BY THE RUSSIAN ARMY IN 1809
\end{abstract}

The intervention of the Russian army in Galicia in June 1809, during the War of the Fifth Coalition, was formally the implementation of the alliance with Napoleon (the Treaty of Tilsit). In reality, Russia was concerned with preventing territorial expansion of the Duchy of Warsaw and hoping for a possible seizure of some Austrian lands. The costs of maintaining the Russian army had to be covered by the inhabitants of the part of Galicia they occupied. The value of food, forage supplies and taxes collected to supply Russian troops, as well as requisitions, amounted at least to 5.87 million florins. That was a serious sum, all the more so because taxes had already been collected from Galicia and the supplies were transferred to the Austrian army. However, these burdens have not led to the collapse of the country's economy. This was partly due to the fact that only the beneficiary of military supplies changed: the Russian army took the place of the Austrian army. The several-month stay of the Russian army in Galicia contributed to the weakening of the economic and military potential of the Habsburg monarchy at the final stage of the war of 1809 , as the state was deprived of the inflow of financial and material resources from its north-eastern areas before the Treaty of Schönbrunn.

Keywords: War of the Fifth Coalition, Galicia, Russian army.

Słowa kluczowe: wojna 1809, Galicja, wojsko rosyjskie.

Kilkumiesięczny pobyt wojsk rosyjskich w Galicji podczas wojny Austrii z napoleońską Europą w 1809 roku nie spotkał się z większym zainteresowaniem ze strony polskich i obcych historyków. Rozpatrywany był zazwyczaj w kontekście kampanii polsko-austriackiej, ewentualnie stosunków francusko-rosyjskich, a konkluzje dotyczyły niemal wyłącznie politycznych implikacji tego faktu. Wskazywano na 
nieformalną współpracę dowództwa rosyjskiego i austriackiego w dziele likwidacji tymczasowej administracji polskiej na wyzwalanych obszarach zaboru austriackiego, dwuznaczną postawę wojsk carskich wobec sił zbrojnych Księstwa Warszawskiego, a wreszcie na wspólnotę celów Wiednia i Petersburga w dziele niedopuszczenia do poszerzenia granic Księstwa Warszawskiego ${ }^{1}$.

Gospodarcze skutki kilkumiesięcznej obecności armii rosyjskiej na tych terenach w zasadzie nie znalazły poważniejszego odzwierciedlenia w literaturze przedmiotu. Jedynie Kazimierz Krzos dokonał szacunku na podstawie danych Rządu Centralnego Obojga Galicji, z którego wynikałoby, że na 48 milionów złotych polskich w bankocetlach (równowartość 12 mln florenów austriackich w bankocetlach) wydanych w okresie jego funkcjonowania na utrzymanie wojsk, około 7,5 miliona złotych polskich, czyli 1,875 miliona florenów, przypadło na zaopatrzenie armii rosyjskiej. Obliczenia te dotyczyły jednak tylko obszarów, które znalazły się pod administracją polską. Nie obejmują zatem cyrkułów pozostających formalnie we władaniu austriackim².

Sytuacja panująca w Galicji od czerwca do listopada 1809 roku była nader skomplikowana. Wojska rosyjskie rozpoczęły swoją interwencję 3 czerwca 1809 roku, forsując Bug i do wygaśnięcia walk na terenie zaboru austriackiego opanowały poważną część kraju wraz ze stołecznym Lwowem. Marsz wojsk carskich zakończył się w połowie lipca 1809 roku w Krakowie wraz z chwilą nadejścia informacji o zawarciu rozejmu austriacko-francuskiego w Znojmie (12 lipca 1809 r.). Wówczas to nastąpił tymczasowy podział Galicji na ziemie znajdujące się pod okupacją i prowizoryczną administracją polską (głównie północne oraz częściowo naddniestrzańskie), na obszary pod okupacją rosyjską z zachowaną administracją austriacką (centralne i częściowo północno-wschodnie), na swoiste kondominium polsko-rosyjskie na terenie Krakowa oraz na obszary podlegające bezpośrednio władzom austriackim (głównie południowe i częściowo wschodnie obszary kraju) ${ }^{3}$.

Czas prowizorki zakończyło podpisanie traktatu pokojowego w Schönbrunn 14 października 1809 roku, na mocy którego Nowa Galicja wraz z okręgiem zamojskim i Podgórzem została wcielona do Księstwa Warszawskiego, saliny wielickie stały się kondominium sasko-austriackim, a okręg tarnopolski przyznany został Rosji. Tereny, które pozostały pod panowaniem austriackim, miały zostać opuszczone przez stacjonujące tu dotychczas oddziały rosyjskie i polskie. W praktyce ewakuacja ta nastąpiła w listopadzie 1809 roku, kończąc tym samym wojenny epizod w dziejach Galicji ${ }^{4}$.

${ }^{1}$ B. Pawłowski, Wojna polsko-austriacka 1809 r., Warszawa 1999, s. 295-299, 345-349, 363-372, 385-398, 419-427; K. Krzos, Z księciem Józefem w Galicji. Rząd Centralny Obojga Galicji, Warszawa 1967, s. 107-114, 128-131, 133-137, 149-150, 178-179, 209-214; zob. też. W. Mejbaum, Rzady austriackie w Galicji (1809-1813), „Biblioteka Warszawska” 1910, t. IV; E. Kipa, Austria a sprawa polska w 1809 roku, Warszawa 1952.

${ }^{2}$ K. Krzos, op. cit., s. 178-179. Dodatkowe dane dotyczące kosztów okupacji wojsk polskich w cyrkule żółkiewskim i złoczowskim znajdują się w: Österreichisches Staatsarchiv/Haus- Hof- und Staatsarchiv, Wien (ÖStA/HHSA), Diplomatie und Außenpolitik vor 1848, Staatskanzlei, Provinzen, Galizien (1775-1851), sygn. 1.

${ }^{3}$ B. Pawłowski, op. cit., s. 419, 432-436.

${ }^{4}$ Austriackie symulacje z końca września 1809 r. zakładały możliwość pobytu wojsk rosyjskich w Galicji do 31 I 1810 r., Центральний державний історичний архів України, Львів [Centralne 
Przemarsze, a następnie kilkumiesięczny pobyt armii rosyjskiej były wielkim obciążeniem dla Galicji. W połowie czerwca 1809 roku czterdziestotysięczny korpus carski był najsilniejszym zgrupowaniem wojskowym w tym kraju. Poza nim w Galicji znajdowały się siły polskie, które (wraz z najnowszymi zaciągami, ochotnikami oraz nowo formowanymi oddziałami, także nieregularnymi) można wówczas oceniać maksymalnie na około 20 000. Wojska austriackie dzieliły się wówczas na kilka odrębnych zgrupowań. Najsilniejsze z nich, VII Korpus arcyksięcia Ferdynanda d'Este, mógł liczyć po poniesionych dotychczas stratach maksymalnie 30000 żołnierzy, a zapewne nieco mniej. Austriackie oddziały zakładowe rozlokowane w Galicji, a przetrzebione masowymi dezercjami oraz poniesionymi stratami bojowymi, liczyły około 10000 wojskowych. Do tego dochodziły trzy formowane dopiero bataliony ochotnicze i ochotniczy pułk kawalerii (razem nie więcej niż 2000 ludzi) oraz oddziały Landwehry śląsko-morawskiej oraz insurekcyjnej kawalerii węgierskiej (razem maksymalnie 12 000) skierowane w trybie nagłym na obszar zaboru austriackiego. Razem dawałoby to blisko 54000 żołnierzy cesarskich 5 .

Po podpisaniu traktatu pokojowego w Schönbrunn (14 października) sytuacja wyglądała już inaczej. Wydaje się, że największą siłę w Galicji tworzyły wówczas oddziały polskie. W listopadzie 1809 roku liczyły one ogółem ponad 52000 żołnierzy, z czego 25000 przypadało na tak zwaną armię galicyjsko-francuską, a 27000 na armię Księstwa Warszawskiego. Szacunkowo ponad $40000 \mathrm{z}$ nich stacjonowało na terenie okupowanej, czy też raczej wyzwolonej Galicji ${ }^{6}$. Niewiele od nich słabsze były siły rosyjskie, natomiast wojska austriackie pozostające w Galicji zostały ograniczone do około 15000 (brygady gen. Johanna Mohra i Maximiliana Merveldta, zgrupowanie Landwehry oraz niektóre oddziały zakładowe) ${ }^{7}$.

Kontyngent rosyjski, niezależnie od naszkicowanych przemian w liczebności wojsk austriackich i polskich w Galicji, był zatem potężnym związkiem wojskowym, którego obecność w istotnym stopniu wpływała na sytuacją ekonomiczną Galicji.

Państwowe Archiwum Historyczne Ukrainy we Lwowie (CPAHUL)], Fond 146, Opis 1, Sprawa 637, s. 14. Dane o dostawach z magazynu w Sanoku dla wojsk rosyjskich dotyczą okresu aż do 9 VIII 1810 r. (!). Być może chodziło w tym przypadku o chorych i maruderów, którzy przebywali w Galicji jeszcze wiele miesięcy po zakończeniu wojny, CPAHUL, Fond 146, Opis 79, Sprawa 109, s. 17.

5 Obliczenia na podstawie: Österreichisches Staatsarchiv/Kriegsarchiv Wien (ÖStA/KA), Musterlisten und Standestabellen (MLST), kartony 91, 497, 588, 671, 758, 941, 1156, 1666, 1868, 1998, 2585, 2683, 3631, 3725, 3960, 4772, 4879, 4964, 4965, 5290, 10181, 10244, 10452, 10453, 10531, 10609, 10610, Standestabellen, Monatstabellen.

${ }^{6}$ K. Krzos, op. cit., s. 218-219; B. Gembarzewski, Wojsko Polskie. Księstwo Warszawskie 1807-1814, Warszawa 1905, s. 17.

${ }^{7}$ B. Pawłowski, op. cit., s. 431-433 oraz dane jak w przyp. 5. Wykaz wojsk austriackich stacjonujących 2 XI 1809 r. w Galicji (bez resztek VII Korpusu i oddziałów zakładowych) wyszczególniał 6 batalionów Landwehry śląsko-morawskiej, 1 batalion piechoty, 1 pułk kawalerii, 1 szwadron kawalerii, baterię artylerii, sztab, komisariat wojskowy oraz intendenturę. Dzienna stawka żywieniowa tej części wojsk wynosiła 8935 porcji chleba, 2614 porcje owsa, 2579 porcji siana, CPAHUL, Fond 146, Opis 1, Sprawa 640, s. 70. W samym tylko cyrkule sądeckim stacjonowało wówczas 950 żołnierzy austriackich z wojsk regularnych, a dla 812 możliwa jest identyfikacja konkretnych związków taktycznych, do których należeli. Ponadto w tymże cyrkule przebywał batalion Landwehry morawskiej i oddział konnego pospolitego ruszenia węgierskiego, CPAHUL, Fond 146, Opis 1, Sprawa 540, s. 23, 32. 
Dla wojska rosyjskiego Galicja nie była terenem nieznanym. Wręcz przeciwnie, w latach 1798-1800 i 1805-1806 miały miejsce przemarsze armii rosyjskiej podążającej do walki z Francją podczas II i III wojny koalicyjnej, a następnie powracającej do kraju w atmosferze klęski. Oficerowie tych wielotysięcznych zgrupowań mogli zatem poznać zasady zaopatrzenia i kwaterunku wojsk obowiązujące w Austrii, a także możliwości aprowizacyjne samej Galicji ${ }^{8}$.

Cele, które zamierzał osiągnąc rząd rosyjski, wydając rozkaz wkroczenia swoim wojskom do Galicji w czerwcu 1809 roku, nie były do końca oczywiste, także dla samych oficerów rosyjskich. Formalnie Rosja szła na pomoc Napoleonowi, a raczej jego wasalowi, jakim było Księstwo Warszawskie. W rzeczywistości celem dywizji rosyjskich było stłumienie wszelkich polskich prób powstańczych w Galicji, niedopuszczenie do przyłączenia jej do Księstwa Warszawskiego oraz unikanie starć zbrojnych z wojskami austriackimi przy jednoczesnym podtrzymywaniu fikcji pełnej współpracy z Napoleonem 9 . Dalej idące konsekwencje obecności wojsk carskich na ziemiach zaboru austriackiego były już mniej oczywiste. Austriacka generalicja przez pewien czas uważała je za nieformalnych sojuszników. Złudzenia te prysły około 17 czerwca 1809 roku, gdy okazało się, że Rosjanie wprawdzie uchylają się od współpracy z wojskami polskimi, ale niedwuznacznie zamierzają objąć w posiadanie jak największe terytorium Galicji, wbrew interesom austriackim ${ }^{10}$. Niosło to za sobą konsekwencje praktyczne. Wojska rosyjskie wchodziły bowiem de iure do kraju nieprzyjacielskiego, ale musiały postępować w sposób maksymalnie oględny, gdyż część zajętych ziem mogła zostać w nieodległej przyszłości wcielona do Rosji. W tej sytuacji bezwzględny wyzysk tych obszarów nie wchodził w rachubę.

Korpus rosyjski, który na początku czerwca 1809 roku przekroczył granicę austriacką, opanował ostatecznie w części lub w całości następujące cyrkuły: bocheński, jasielski, tarnowski, rzeszowski, sanocki, samborski, przemyski, złoczowski, brzeżański, lwowski i stryjski ${ }^{11}$. W Nowej Galicji żołnierze rosyjscy znaleźli się czasowo na terenie cyrkułu krakowskiego, siedleckiego i radomskiego. W pojedynczych przypadkach oficerowie rosyjscy domagali się dostaw z ziem znajdujących się poza granicami ich okupacji. Do takich incydentów dochodziło szczególnie w cyrkule sądeckim. W skrajnych przypadkach prowadziły one do zorganizowanych rajdów oddziałów rosyjskich (na ogół kawalerii) na obszary będące pod formalną kontrolą austriacką i dokonywania rekwizycji, czy też raczej rabunku, znajdujących się tam zapasów żywności i furażu ${ }^{12}$.

Według zestawienia sporządzonego w 1818 roku koszt utrzymania wojsk rosyjskich przez poszczególne cyrkuły Starej Galicji (bez cyrkułu zamojskiego) kształtował się następująco.

${ }^{8}$ Część żołnierzy rosyjskich (ranni, chorzy, rekonwalescenci) pozostała w Galicji dłużej i została umieszczona w szpitalach przeznaczonych wyłącznie dla nich, Archiwum Narodowe w Krakowie (ANK), Magistrat Miasta Krakowa I (Mag) I/229, s. 671-677, 689-693.

${ }^{9}$ B. Pawłowski, op. cit., s. 187-190.

${ }^{10}$ Ibidem, s. 321-323, 346-349, 413.

${ }^{11}$ CPAHUL, Fond 146, Opis 79, Sprawa 90, s. 43.

12 CPAHUL, Fond 146, Opis 1, Sprawa 545, s. 18-41. 
Tabela 1. Wydatki cyrkułów Starej Galicji na utrzymanie wojsk rosyjskich w 1809 roku

\begin{tabular}{|c|c|}
\hline Cyrkut & Wartość dostaw (floreny) \\
\hline Bocheński & 274246 \\
\hline Jasielski & 253982 \\
\hline Tarnowski & 344499 \\
\hline Rzeszowski & 380624 \\
\hline Sanocki & 422631 \\
\hline Samborski & 408206 \\
\hline Przemyski & 518283 \\
\hline Złoczowski & 329061 \\
\hline Brzeżański & 439655 \\
\hline Lwowski & 374679 \\
\hline Stryjski & 216674 \\
\hline RAZEM & 3949674 \\
\hline
\end{tabular}

Źródło: CPAHUL, Fond 146, Opis 79, Sprawa 90, s. 43.

Na kwotę tę składały się:

- jednoroczny podatek dominikalny i rustykalny: 520158 florenów;

- półroczny podatek dominikalny i rustykalny: 260079 florenów;

- opłata dzierżawców dóbr: 98199 florenów;

- opłata duchowieństwa rzymskokatolickiego: 40348 florenów;

- fundusz kwaterunkowy miast: 104721 florenów;

- opłata rzemieślników większych miast: 24700 florenów;

- opłata rodzin żydowskich (pogłówne): 142040 florenów;

- wartość liwerunków: 2759293 florenów.

Dawało to razem sumę 3949541 florenów, nieznacznie tylko różniącą się od kwoty wynikającej z zestawienia łącznego dla poszczególnych cyrkułów ${ }^{13}$. Wojsko rosyjskie otrzymało zatem przede wszystkim gotówkę oraz żyto, mąkę, owies i siano w naturze. Część niezbędnych środków dla armii pozyskano w wyniku rekwizycji. Według zestawienia sporządzonego w 1818 roku składały się na nie:

- żyto: 4791 korców;

- mąka: 20911 cetnarów;

- chleb: 27795 cetnarów;

- owies: 179887 korców;

- siano: 254072 cetnary;

${ }_{13}$ CPAHUL, Fond 146, Opis 79, Sprawa 90, s. 1-2. Zob. też: Österreichisches Staatsarchiv/Finanzund Hofkammerarchiv Wien (ÖStA/FHKA) Präsidialakten der k.k. Hofkammer und des k.k. Finanzministeriums (FHKA Pr., 1797-1918), Hofkammer-geheime Präsidialakten (HKG Pr., 1804-1824), Akten des Hofkammerpräsidenten Graf O'Donell, kartony 82-83 oraz ÖStA/KA, Alte Feldakten (AFA), kartony $1390-1392,1432$. 
- słoma: 19109 cetnarów;

- kasza: 175711 garnców;

- olej lniany: 1 garniec;

- wołowina: 127583 funty;

- wódka: 92173 garnce;

- piwo: 30231 garnców;

- sól: 28294 garnce;

- sól twarda: 996 sążni;

- drewno: 3084 sążnie;

- świece: 2742 funty;

- gotówka: 47800 florenów.

Wartość tych dostaw oszacowano na 579669 florenów. Natomiast wartość liwerunków z dóbr kameralnych oceniono na 594660 florenów ${ }^{14}$. Ponadto z terenu cyrkułu sądeckiego, niewyszczególnionego w powyższych zestawieniach, wojsko rosyjskie uzyskało dodatkowe korzyści z tytułu rekwizycji w wysokości 44096 florenów, na co złożyło się: 636 korców żyta, 2630 korców owsa, 4866 cetnarów siana, 978 garnców wódki, 89 korców kaszy, 101 sztuk bydła ${ }^{15}$.

Koszt utrzymania wojsk rosyjskich w Galicji okazał się nadspodziewanie wysoki. Według zestawienia sporządzonego już 14 października 1809 roku wysokość rekwizycji z jednego tylko cyrkułu bocheńskiego osiągnęła 80000 florenów, podczas gdy suma dochodów tego cyrkułu wynosiła według fasji z 1. 1774-1775 tylko 60495 florenów $^{16}$. Niezależnie od tego, czy podawane informacje były zgodne z prawdą, obecność wojsk rosyjskich wywarła poważny wpływ na sytuację finansową poszczególnych cyrkułów galicyjskich. Administracja rosyjska przejęła ponadto środki miejskich funduszów kwaterowych, wykorzystując zbierane w nich fundusze na własne cele. $Z$ niektórych miast ściągnięto przy tej okazji całkiem pokaźne sumy. Najwięcej wypłaciły Brody - 4402 florenów, następnie Sambor - 1354 florenów, Tarnów - 1302 florenów, Przemyśl - 1082 florenów, Bochnia 1010 florenów ${ }^{17}$.

Wielkość i sposób organizacji dostaw dla wojsk rosyjskich wywołały prawdziwą burzę wśród szlachty galicyjskiej. Ujawniają to zachowane dokumenty z cyrkułu jasielskiego. Ks. Siergiej Golicyn, dowódca rosyjskiego korpusu interwencyjnego, wskutek kierowanych do niego skarg szlachty cyrkułu jasielskiego udzielił zgody na utworzenie tymczasowej komisji szlacheckiej, która miała się zająć ustalaniem wysokości świadczeń już ściągniętych przez wojska rosyjskie oraz sprawdzeniem i gromadzeniem kwitów oraz nakazów rekwizycyjnych. Na mocy tego rozporządzenia zebrała się reprezentacja szlachty (Antoni Stadnicki, Antoni Rommer, Cyprian Rommer, Adam Grodziński) i zorganizowała się w komisję, budząc tym samym ogromne zaniepokojenie austriackich władz cyrkularnych w Jaśle. Interpretowały one zaistniałą sytuację jako samodzielne wystąpienie polskiej szlachty, która nawiązała na

${ }^{14} \mathrm{Z}$ dóbr kameralnych (ekonomia niepołomicka) pochodziły między innymi dostawy drewna opałowego dla armii rosyjskiej, CPAHUL, Fond 146, Opis 65, Sprawa 376, s. 1-15.

${ }_{15}$ CPAHUL, Fond 146, Opis 79, Sprawa 90, s. 28, 39, 42; Fond 146, Opis 1, Sprawa 639, s. 11.

${ }_{16}$ CPAHUL, Fond 146, Opis 79, Sprawa 91, s. 8.

${ }^{17}$ CPAHUL, Fond 146, Opis 79, Sprawa 92, s. 21, 33; Sprawa 93, s. 7, 40; Sprawa 94, s. 27. 
własną rękę współpracę z wojskami rosyjskimi. Po dłuższych dyskusjach do wspomnianego grona weszli ostatecznie: Aleksander Biliński, Antoni Rommer i Bernard Lewartowski. Mieli oni prowadzić księgi rachunkowe świadczeń na rzecz armii rosyjskiej oraz ustalić faktyczną wysokość dostaw.

Około 15 sierpnia delegacja szlachty galicyjskiej (Antoni Stadnicki, Józef Stojowski, Cyprian Rommer, Adam Grodziński) nawiązała formalny kontakt z urzędem cyrkularnym w Jaśle. Ten ostatni bardzo niechętnie udzielił warunkowej zgody na jej działanie, jednocześnie wszakże deklarując, że nie ma ona żadnej mocy prawnej, a tym samym że komisja działała i działa nielegalnie (!) ${ }^{18}$. Być może pod wpływem takich oddolnych inicjatyw szlachty polskiej władze austriackie podjęły decyzję o utworzeniu specjalnego funduszu na rzecz utrzymania armii rosyjskiej. Wiadomo, że funkcjonował on na terenie cyrkułu bocheńskiego i tarnowskiego ${ }^{19}$.

Wielkie kontrowersje wywołał sposób realizacji żądań armii rosyjskiej przez Antoniego Stadnickiego z Nawojowej. Cała sprawa nie jest do końca jasna. Z dominium Nawojowa przekazano dla wojsk rosyjskich żywność rzekomo na kwotę 23000 florenów (woły, kasza, wódka), która nie została przez nikogo opłacona. Właściciel zlekceważył w tym momencie dyrektywy władz i zamiast do Nowego Sącza dostarczył na własną rękę liwerunek do Wieliczki, będącej w rękach rosyjskich. Konflikt na tym tle $\mathrm{z}$ władzami austriackimi (komisariat w Tarnowie) doprowadził do zastosowania wobec niego egzekucji wojskowej (przymusowe zakwaterowanie żołnierzy w Nawojowej). Stadnicki wystosował protest w tej sprawie, który został wówczas zignorowany ${ }^{20}$.

Cały ten spór, bardzo słabo uchwytny w zachowanym materiale archiwalnym, wymaga nieco głębszej analizy. Nie ulega wątpliwości, że był on próbą emancypacji politycznej szlachty cyrkułu jasielskiego i sądeckiego oraz stworzenia przez nią struktur konkurencyjnych wobec niewydolnej biurokracji austriackiej. Dla władz cesarskich oznaczało to tym samym swoiste wotum nieufności wobec urzędników habsburskich. W dalszej perspektywie mogło natomiast prowadzić do poddania się szlachty galicyjskiej carowi Aleksandrowi I. Ten zaś prowadził wobec „swoich” Polaków politykę pojednania i ugody, całkiem inną niż ta preferowana przez centralistyczną i germanizacyjną biurokrację wiedeńską ${ }^{21}$. Nic też dziwnego, że samodzielne inicjatywy i propozycje szlachty galicyjskiej w kwestii zaprowiantowania wojsk rosyjskich były przez władze austriackie postrzegane przez pryzmat sympatii politycznych polskiego ziemiaństwa.

Nadmierne żądania strony rosyjskiej, a dotyczące także ziem pozostających formalnie pod kontrolą austriacką, budziły ogromne kontrowersje w zaborze austriackim i ostatecznie nie przyczyniły się do budowy dobrej opinii wojsk i państwa carskiego. W myśl instrukcji wydanej 14 września 1809 roku przez dowództwo wojskowe w Nowym Sączu znajdujące się tam trzy kompanie Landwehry morawskiej oraz oddziały konnej insurekcji węgierskiej miały skoncentrować się nie tylko na

\footnotetext{
${ }_{18}$ CPAHUL, Fond 146, Opis 1, Sprawa 638, s. 1-8.

19 CPAHUL, Fond 146, Opis 79, Sprawa 99, s. 1-133 oraz Sprawy 91-97.

${ }^{20}$ CPAHUL, Fond 146, Opis 1, Sprawa 643, s. 5-26.

${ }^{21}$ Zob. B. Pawłowski, op. cit., s. 345-349.
} 
zwalczaniu bandytyzmu, lecz przede wszystkim na blokowaniu działań rosyjskiego pułku kozaków stacjonującego w Ciężkowicach, by ten nie prowadził żadnych akcji wypadowych na południe. Pod względem zależności służbowej jednostki austriackie należały do zgrupowania feldmarszałka porucznika Ignaza von Eggermanna, ale w rzeczywistości podlegały rozkazom brygadiera, generała majora Johanna Friedricha von Mohra, z którym miały lepszy i bliższy kontakt ${ }^{22}$. Instrukcja ta była odpowiedzią na zagony rosyjskiej kawalerii w sierpniu 1809 roku, która dokonywała rekwizycji, a w praktyce ordynarnych rabunków na ziemi limanowskiej, podlegającej wciąż jurysdykcji austriackiej²3.

Ostatecznie Austriacy ugięli się wobec roszczeń rosyjskich. We wrześniu 1809 roku liczne dominia z cyrkułu sądeckiego zostały zmuszone przez władze habsburskie do realizacji dostaw na rzecz armii carskiej, które kierowano do Ciężkowic ${ }^{24}$. Uniknięto w ten sposób bezpośrednich rekwizycji na rzecz przeciwnika, ale nie zdołano zatrzeć wrażenia całkowitej klęski politycznej i militarnej.

Galicyjscy właściciele ziemscy skrupulatnie notowali swoje szkody związane z okupacją rosyjską. Najlepiej chyba udokumentowane straty pochodziły z dominium Kokotów-Zabawa (cyrkuł bocheński). W myśl zbiorczych zestawień wojska rosyjskie wypasało swoje konie na łąkach dominikalnych i rustykalnych dominium, całkowicie je niszcząc. Zmarnowano w ten sposób zbiór szacowany na 4471 cetnarów siana o wartości 22336 florenów ( 1 cetnar $=5$ fl.). Wartość utraconego sprzężaju (20 koni, 4 i pół wozu, 80 worków) oszacowano na 2885 florenów (wartość konia: 60-118 fl.), natomiast wartość dostarczonego chleba w okresie 16 lipca-12 listopada 1809 roku oceniono na 2536 florenów.

Do 13 sierpnia 1809 roku wydano dla 9. dywizji rosyjskiej oraz 2. dywizji rosyjskiej ${ }^{25}$ (głuchowskiego pułku kirasjerów, noworosyjskiego pułku dragonów, 10. pułku jegrów oraz artylerii) z dominium Kokotów-Zabawa następujące towary:

- mąka: 7572 funty polskie;

- owies: 212 korców;

- siano: 1000 porcji 10-funtowych (100 cetnarów);

- wódka: 84 garnce;

- bydło: 6 sztuk.

Kolejna dostawa z Kokotowa z 8 września 1809 roku obejmowała następujące produkty:

- mąka: 4394 funty polskie;

- owies: 88 korców;

- siano: 176 cetnarów;

${ }^{22}$ CPAHUL, Fond 146, Opis 1, Sprawa 545, s. 18.

${ }^{23}$ CPAHUL, Fond 146, Opis 1, Sprawa 640, s. 7-13. Beneficjentem tych „dostaw” była głównie 9. dywizja rosyjska gen. Aleksandra Suworowa.

${ }^{24}$ CPAHUL, Fond 146, Opis 1, Sprawa 545, s. 25-41. Przykładowo pułk kozaków Karasja (409 ludzi i 498 koni) miał otrzymywać 366 cetnarów chleba, 61 cetnarów mięsa, 19 korców gryki, 386 garnców wódki, 1533 korce jęczmienia i 858 cetnarów siana na miesiąc, ibidem.

${ }^{25}$ Rosyjski korpus interwencyjny składał się z 9., 10., 18. i 24. dywizji piechoty. Zapewne chodziło w tym przypadku o 2. dywizję kawalerii rosyjskiej. 
- wódka: 114 garnców;

- kasza lub groch: 85 garnców.

W październiku 1809 roku dostarczono z dominium:

- mąka: 4536 funtów;

- kasza: 128 kwart;

- wódka: 264 kwarty;

- mięso: 215 funtów.

Ostatnia duża dostawa z dominium Kokotów-Zabawa (przewidziana do realizacji aż do 31 stycznia 1810 roku) obejmowała następujące produkty:

- mąka: 108,45 cetnarów;

- owies: 509 i 19/32 korców;

- siano: 299,51 cetnara.

Ponadto od 20 sierpnia do 20 listopada 1809 roku dostarczono z dominium Kokotów-Zabawa dla wojsk rosyjskich 34 sągi drewna jako materiał opałowy ${ }^{26}$. Powyższe informacje, niezależnie od możliwego zawyżenia cen dostarczonych produktów, pokazują skalę wyzysku jednego tylko dominium przez wojsko rosyjskie w 1809 roku.

Niewiele lepiej kształtowała się sytuacja na terytoriach odebranych Austrii, które znalazły się pod kontrolą prowizorycznych władz polskich (Rząd Centralny Obojga Galicji). Tam, gdzie stacjonowały oddziały rosyjskie, utrzymanie ich spadało na okoliczne miasta i dominia. W myśl rozkazu księcia Józefa Poniatowskiego z 20 lipca 1809 roku na koszt Krakowa miała być utrzymywana rosyjska brygada generała Karla Sieversa. Stawka żywieniowa brygady narzucona na miasto wynosiła: 2383 funty wiedeńskie mięsa i 4766 racji (149 garnców) wódki dziennie. Liwerantami ze strony miasta był Berko Neyberger oraz zapewne Wolf Markusfeld. Zboże, mąkę i siano miały przekazać okoliczne dominia. Wartość dostarczanego mięsa i wódki wynosiła 6814 złotych polskich (1704 fl. w bankocetlach) dziennie. Do chwili opuszczenia przez nich Krakowa miasto opłaciło dostawy dla wojsk rosyjskich w wysokości 442910 złotych polskich (110 928 fl. w bankocetlach $)^{27}$. Natomiast łączna wartość żywności i furażu przekazanych armii rosyjskiej z ziem Galicji znajdujących się pod administracją polską wynieść miała 7,5 miliona złotych polskich $(1,875 \mathrm{mln} \text { fl. })^{28}$.

Po dodaniu powyższej sumy do kwot i wartości towarów uzyskanych z ziem znajdujących się bezpośrednio pod okupacją rosyjską oraz z cyrkułu sądeckiego, które wyniosły razem około 4 milionów florenów, otrzymujemy około 5,875 miliona florenów, które wydatkowano na utrzymanie wojsk carskich w 1809 roku w Galicji. Był to potężny wysiłek dla kraju, z którego zebrano już, oprócz zwyczajnych podatków

${ }^{26}$ CPAHUL, Fond 146, Opis 79, Sprawa 99, s. 17-84. Dla porównania: wartość wszystkich dostaw z dominium Krakowiec dla armii rosyjskiej w 1809 r. obliczono następnie na 24440 fl., ibidem, Sprawa 100.

${ }_{27}$ M. Baczkowski, Wojsko polskie w napoleońskim Krakowie, Kraków 2009, s. 85-86; ANK, Mag I/238, s. 15, 497, 779. Ustalenie wysokości sum wydatkowanych na wojsko rosyjskie przez poszczególne cyrkuły (lub ich części) znajdujące się w 1809 r. pod prowizoryczną jurysdykcją polską jest w praktyce niemożliwe. K. Krzos szacował całość wydatków na utrzymanie wojsk polskich (i o wiele słabszych liczebnie) wojsk rosyjskich na terenie obszarów, które znalazły się w 1809 r. pod czasową kontrolą polską, na 48 mln zł polskich (12 mln fl. w bankocetlach), K. Krzos, op. cit., s. 88-89.

${ }^{28}$ K. Krzos, op. cit., s. 179. 
i kontrybucji wojennej, podatki liwerunkowe (prawie 739 tys. fl.) oraz pokaźne zapasy żywności, w tym 72618 cetnarów mąki i 404406 mac żyta dla wojsk habsburskich w pierwszym półroczu 1809 roku, a następnie jeszcze 155092 mace żyta i 257204 mace owsa. Do tego wybrano pokaźny kontyngent rekruta na rzecz armii austriackiej, co dodatkowo przyczyniło się do perturbacji gospodarczych w kraju ${ }^{29}$.

Jeszcze większe środki wykorzystano na rzecz utrzymania i rozbudowy wojsk polskich, które zajęły część Galicji od maja do połowy lipca 1809 roku. Przeznaczono na nie szacunkowo około 40,5 miliona złotych polskich $(10,125 \mathrm{mln} \mathrm{fl}$.), w tym 21,5 miliona złotych polskich $\left(5,375 \mathrm{mln}\right.$ fl.) na wystawienie nowych oddziałów ${ }^{30}$.

W świetle zachowanych akt niemal nic nie wiadomo na temat dewastacji własności państwowej i prywatnej przez okupacyjne wojska rosyjskie. Jest to dość dziwne, gdyż wszystkie armie w dobie wojen napoleońskich dokonywały najrozmaitszych zniszczeń budynków gospodarczych, łąk, pól uprawnych itp. Były one rezultatem poszukiwania przez żołnierzy materiałów opałowych, żywności, zwiększonego wypasu koni, pospolitych rabunków, a wreszcie rezultatem zakwaterowania oddziałów wojskowych w miejscach całkowicie nienadających się do tych zadań. Informacje na temat rozmaitych dewastacji poczynionych podczas wojny 1809 roku pochodzą na przykład z Krakowa, a przede wszystkim z folwarków należących do miasta. Ich sprawcami byli zarówno żołnierze rosyjscy, jak i polscy ${ }^{31}$. Z kolei według źródeł austriackich „polscy powstańcy” w samych tylko Monasterzyskach dokonali różnorakich szkód (ale raczej rekwizycji i zaboru miejscowej kasy niż dewastacji i rabunku własności prywatnej) na kwotę 10766 florenów ${ }^{32}$.

Natomiast $w$ zachowanych materiałach $\mathrm{z}$ terenów austriackiej Galicji, w tym także w zbiorczych spisach świadczeń na rzecz armii rosyjskiej, brak jest zupełnie informacji tego typu. Na pewno ich nieobecność nie wynika z krystalicznie uczciwego zachowania się żołnierzy rosyjskich w 1809 roku, gdyż wojska wszystkich państw, także carskie, łamały obowiązujące wówczas normy prawne. Natomiast brak informacji na ten temat może, choć nie musi, być dowodem na to, że po Kongresie Wiedeńskim władze austriackie nie chciały stawiać tej kwestii na ostrzu noża i były skłonne do rezygnacji z ewentualnych roszczeń swoich poddanych w imię utrzymania dobrych stosunków z państwem Aleksandra I. Inna rzecz, że gdy wojska rosyjskie poddane były ostrej dyscyplinie, to skala wyrządzanych przez nie szkód była o wiele mniejsza niż np. armii napoleońskiej.

Faktyczny koszt utrzymania armii rosyjskiej w Galicji był przez dłuższy czas obiektem sporów, a sporządzane na gorąco szacunki były mocno nieprecyzyjne. Pierwsze dokładniejsze obliczenia przeprowadzono dopiero w 1815 roku, a trzy lata później, 12 czerwca 1818 roku ustalono ostateczną sumę przypadającą na tę część

${ }^{29}$ ANK, Mag I/195, s. 589, 611, 615, 627, 637; CPAHUL, Fond 146, Opis 7, Sprawa 380, s. 5, 44, 81. Oddziały austriackie także uciekały się do rekwizycji potrzebnych środków. Przypadki takie zanotowano w cyrkułach sądeckim i myślenickim, a objęły one chleb, mięso, grykę, wódkę, siano i słomę, CPAHUL, Fond 146, Opis 1, Sprawa 540.

${ }^{30}$ CPAHUL, Fond 146, Opis 1, Sprawa 637, s. 18; K. Krzos, op. cit., s. 179-180, 219.

${ }^{31}$ ANK, Mag I/242, s. 927, 959.

32 CPAHUL, Fond 146, Opis 7, Sprawa 393, s. 23. 
Galicji, która po Kongresie Wiedeńskim znajdowała się w rękach austriackich. W rezultacie utworzony został wówczas specjalny fundusz zaopatrzenia armii rosyjskiej, którego celem było dokonanie rozliczeń z poszkodowanymi dominiami. Dokonywano z niego wypłat co najmniej do 1842 roku, a kwestię rozliczeń zamknięto dopiero w 1848 roku $^{33}$.

Interwencja wojsk rosyjskich w Galicji w 1809 roku zakończyła się tylko częściowym sukcesem. Ich obecność przyczyniła się z jednej strony do wyhamowania fali powstańczej we Wschodniej Galicji i pośrednio do utraty Lwowa przez Polaków. $\mathrm{Z}$ drugiej jednak strony w dużym stopniu sparaliżowała aktywność wojsk cesarskich i wymusiła ich odwrót $\mathrm{z}$ wielu cyrkułów, co w istotny sposób osłabiło habsburski potencjał militarny. Głównego celu - niedopuszczenia do rozszerzenia terytorialnego Księstwa Warszawskiego nie udało się jednak osiągnąć. Skromną rekompensatą dla Rosji było w tej sytuacji otrzymanie wschodnich rejonów Galicji, tak zwanego kraju tarnopolskiego.

Koszty działań wojsk rosyjskich w 1809 roku spadły na barki mieszkańców połowy cyrkułów Galicji. Był to dla nich kolejny cios po uprzednim ściągnięciu ogromnych podatków oraz dostaw na potrzeby armii austriackiej wiosną tego roku. Mimo wszystko wojska carskie zachowały na ogół karność i dyscyplinę, dzięki czemu uniknięto rabunków i bezmyślnej dewastacji, która na ziemiach polskich była w latach 1806-1807 i w 1812 roku dziełem armii napoleońskiej. Straty materialne Galicji były poważne, ale koszt utrzymania armii rosyjskiej nie doprowadził do załamania gospodarczego w kraju, ani nie był głównym czynnikiem częściowego bankructwa całego państwa w 1811 roku. W jakimś stopniu potwierdzają to dane ludnościowe, gdyż z austriackich spisów statystycznych (szczególnie za lata 1807-1816) wynika, że czas wojen napoleońskich nie przyniósł osłabienia przyrostu demograficznego w zaborze austriackim, a większość osad notowała w tym okresie stały wzrost liczby mieszkańców ${ }^{34}$.

Bezpośrednio po zakończeniu wojny, w 1810 roku, w zmniejszonej już terytorialnie Galicji władze austriackie rozlokowały pięć pułków piechoty, pięć pułków kawalerii, dwa bataliony grenadierów, siedem dywizjonów i dwanaście kompanii zakładowych pułków piechoty, a także oddziały artylerii i tabory ${ }^{35}$. Szacunkowo siły te liczyły co najmniej 30 tysięcy żołnierzy, a ich pobyt nie wywołał widocznych wstrząsów gospodarczych w kraju. Świadczy to na rzecz tezy, iż mimo że pobyt wojsk

${ }^{33}$ CPAHUL, Fond 146, Opis 79, Sprawy 70, s. 106-109.

${ }^{34}$ Ł. Jewuła, Galicyjskie miasta i miasteczka oraz ich mieszkańcy w latach 1772-1848, Kraków 2013, aneks.

${ }_{35}$ Obliczenia na podstawie: A. von Wrede, Geschichte der $k$. und $k$. Wehrmacht, Bd. I-V, Wien 1898-1903, wykazy pułków. Według symulacji austriackich w 1810 r. w Galicji miało stacjonować 20 batalionów piechoty (lub sześć pułków piechoty), cztery bataliony kordonu granicznego, pięć pułków lekkiej kawalerii, artyleria, dywizjon transportów i generalicja. Dzienna stawka żywieniowa dla garnizonów galicyjskich była przewidziana na 38248 porcji chleba, 10709 porcji owsa, 10327 porcji siana, CPAHUL, Fond 146, Opis 1, Sprawa 640, s. 66. Niepełny (bez mięsa, kaszy, drewna) wykaz dostaw wojskowych z Galicji dla tutejszych garnizonów w 1810 r. przewidywał dostarczenie 183492 cetnarów mąki lub zamiennie 275238 mac żyta, 608568 mac owsa, 452596 cetnarów siana, CPAHUL, Fond 146, Opis 1, Sprawa 637, s. 1-9, 21. 
rosyjskich był nader uciążliwy dla mieszkańców, to nie wywarł większego wpływu na panujące tu realia gospodarcze.

W rezultacie stosunkowo krótki epizod okupacji znacznej części Galicji przez wojsko rosyjskie został dość szybko zapomniany. Jedynie właściciele dominiów dotkniętych przymusowymi dostawami lub rekwizycjami na rzecz armii carskiej usiłowali w kolejnych latach uzyskać stosowne rekompensaty od władz austriackich. Te ostatnie nie były skłonne do szybkiego zadośćuczynienia poszkodowanym, niemniej w latach trzydziestych i czterdziestych XIX wieku wypłaciły niewielkie odszkodowania zainteresowanym. Wówczas to dopiero zakończył się czas rozliczeń finansowych związanych z okupacją Galicji przez wojsko rosyjskie.

Należy przy tym zauważyć, że obecność wojsk carskich na ziemiach zaboru austriackiego wymuszała na ich mieszkańcach kolejne dostawy i świadczenia pieniężne, ale z drugiej strony przerwała analogiczne świadczenia realizowane na rzecz wojsk habsburskich. Cyrkuły zaś, które pozostały w rękach austriackich (np. myślenicki i sądecki), stale dostarczały żywności i furażu dla oddziałów cesarskich ${ }^{36}$. Dlatego też obecność wojsk rosyjskich oznaczała głównie zmianę beneficjenta świadczeń. Na koniec nie sposób powstrzymać się od uwagi, że per saldo rosyjska okupacja Galicji poważnie osłabiła potencjał militarno-ekonomiczny państwa habsburskiego w końcowej fazie kampanii 1809 roku, a szczególnie podczas długotrwałych negocjacji w przededniu podpisania pokoju w Schönbrunn. Sprowadzenie Austrii do rangi mocarstwa drugiej kategorii, co było następstwem tego traktatu, nie było przecież głównym celem polityki Rosji wysyłającej swój korpus do Galicji. Rezultaty czasowej okupacji znacznej części zaboru austriackiego przez armię rosyjską można ocenić jako niepowodzenie polityczne Petersburga, ale zarazem za bardzo „tani” sposób na zademonstrowanie swojej siły militarnej.

\section{BIBLIOGRAFIA}

\section{Źródła archiwalne}

Archiwum Narodowe w Krakowie (ANK)

Magistrat Miasta Krakowa I

Mag I/195, 229, 238, 242

Österreichisches Staatsarchiv/Finanz- und Hofkammerarchiv Wien (ÖStA/FHKA)

Präsidialakten der k.k. Hofkammer und des k.k. Finanzministeriums (FHKA Pr., 1797-1918)

${ }^{36}$ CPAHUL, Fond 146, Opis 1, Sprawa 540, s. 24-44; Z cyrkułu myślenickiego do 30 X 1809 r. wojskom austriackim dostarczono: żyto (13 $589 \mathrm{mac}$ ), owies (36 $418 \mathrm{mac})$, mąkę (30 cetnarów), chleb (10 000 bochenków i 88012 porcji), groch (182 mace), kaszę (37 mac), siano (11 132 cetnary), słomę na sienniki (400 cetnarów), słomę na podściółkę (178 cetnarów), wódkę (840 garnców), woły (300 sztuk) oraz drewno (111 sążni i 100 fur), CPAHUL, Fond 146, Opis 1, Sprawa 635, s. 9-21. 
Hofkammer-geheime Präsidialakten (HKG Pr., 1804-1824), Akten des Hofkammerpräsidenten Graf O’Donell, kartony 82-83

Österreichisches Staatsarchiv/Haus- Hof- und Staatsarchiv, Wien (ÖStA/HHSA)

Diplomatie und Außenpolitik vor 1848, Staatskanzlei, Provinzen, Galizien (1775-1851), sygn. 1 .

Österreichisches Staatsarchiv/Kriegsarchiv Wien (ÖStA/KA)

Musterlisten und Standestabellen (MLST), kartony 91, 497, 588, 671, 758, 941, 1156, 1666, 1868, 1998, 2585, 2683, 3631, 3725, 3960, 4772, 4879, 4964, 4965, 5290, 10181, 10244, 10452, 10453, 10531, 10609, 10610

Alte Feldakten (AFA), kartony 1390-1392, 1432

Центральний державний історичний архів України, Львів [Centralne Państwowe Archiwum Historyczne Ukrainy we Lwowie], (CPAHUL)

Fond 146, Opis 1, Sprawy 540, 545, 637-640, 643

Fond 146, Opis 7, Sprawy 380, 393

Fond 146, Opis 65, Sprawa 376

Fond 146, Opis 79, Sprawy 70, 90-94, 97-99, 106-109

\section{Opracowania}

Baczkowski M., Wojsko polskie w napoleońskim Krakowie, Kraków 2009.

Gembarzewski B., Wojsko Polskie. Księstwo Warszawskie 1807-1814, Warszawa 1905.

Jewuła Ł., Galicyjskie miasta i miasteczka oraz ich mieszkańcy w latach 1772-1848, Kraków 2013.

Kipa E., Austria a sprawa polska w 1809 roku, Warszawa 1952.

Krzos K., Z księciem Józefem w Galicji. Rząd Centralny Obojga Galicji, Warszawa 1967.

Mejbaum W., Rzady austriackie w Galicji (1809-1813), „Biblioteka Warszawska” 1910, t. IV.

Pawłowski B., Wojna polsko-austriacka 1809 r., Warszawa 1999.

Wrede A. von, Geschichte der k. und k. Wehrmacht, Bd. I-V, Wien 1898-1903. 